\title{
ГОСПОДАРСЬКИ КОРИСНІ ЯКОСТІ СВИНОМАТОК ПОРОДИ ЛАНДРАС ТА ВЕЛИКА БІЛА ЗА ЧИСТОПОРОДНОГО РОЗВЕДЕННЯ, СХРЕЩУВАННЯ ТА ГІБРИДИЗАЦІЇ В УМОВАХ ПРОМИСЛОВОГО КОМПЛЕКСУ
}

\author{
Карпенко Богдан Миколайович \\ аспірант, спеціальність 204-ТВППТ \\ Сумський національний аграрний університет \\ ORCID: 0000-0002-9942-5863 \\ E-mail: karpenkobogdan95@gmail.com
}

Досліджували відтворні якості свиноматок різного походження ірландської селекції: чистопородні ландрас

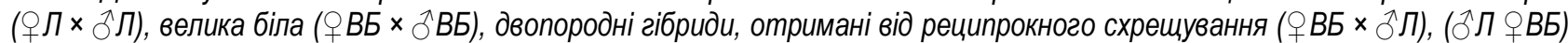
та фінальні гібриди, отримані від схрещування двопородних гібридних свиноматок з кнурами синтетичної лінії «Максгро» (Mr). Експерименти проведено в умовах промислового свинокомплексу ТОВ «НВП «Глобинський свинокомплекс». Порівняльний аналіз показників, які характеризують відтворну здатність чистопородних свиноматок породи ландрас та велика біла, міжпородної різниці не виявив. Оцінка двопородних гібридів, показники на користь свиноматок ㅇ ВБ × $\widehat{\jmath}$ Л за кількістю народжених поросят (+0,6 гол.), багатоплідністю $(+0,56$ гол.), масою гнізда при народження $(+0,37$ ке), масою поросят при відлученні $(+0,23)$ за недостовірної різниці. Проте свиноматки 으 × ${ }^{\jmath} Л$ поступалися за кількістю поросят при відлученні з достовірною різницею на 0,7 гол. $(P<0,05)$ за рахунок гіршої збереженості поросят у свиноматок $9 Л \times{ }^{\top} B Б$ на $6,73 \%$ за достовірної різниці $(P<0,01)$. За порівняння

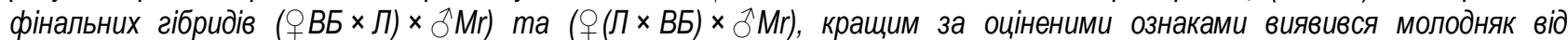

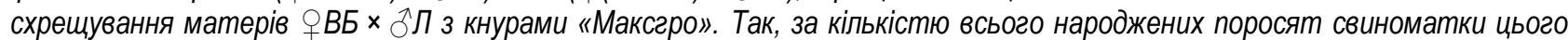
поєднання перевищували інші піддослідні групи свиноматок на 0,7-1,76 гол. Достовірна різниия за даною ознакою виявлена при порівнянні з I $(P<0,001)$ ma III $(P<0,05)$ групами. Вдале поєднання материнської основи двопородних гібридів з батьківською синтетичною лінією «Максгро» дозволило отримати ефрект гетерозису за ознаками приросту живої маси

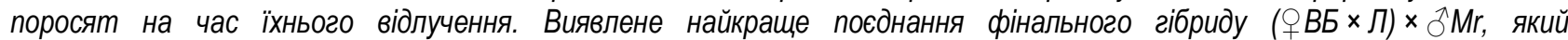

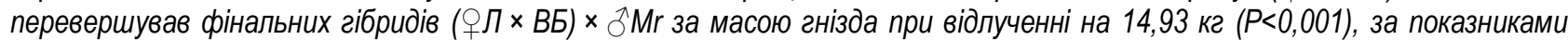
приросту живої маси поросят: середньодобовим - на 36,31 г ( $(P<0,01)$, абсолютним - на 0,98 ке $(P<0,01)$ та відносним - на $5,04 \%(P<0,05)$. Вони також переважали поросят отриманих від чистопородних свиноматок та їх двопородних гібридів

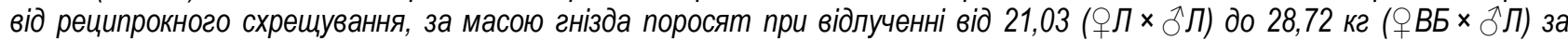
високодостовірної різниці при $P<0,001$. За приростами живої маси: середньодобовому, абсолютному та відносному фінальні гібриди (В ВБ × Л) × ${ }^{\top} \mathrm{Mr}$ переважають поросят I-IV груп з мінливістю відповідно на 47,86-68,10 г (P<0,001), 1,27$1,84$ ке $(P<0,001)$ ma 3,98-10,29\% (H/d - $P<0,001)$.

Ключові слова: ландрас, велика біла, максеро, порода, свиноматки, поросята, відтворні якості, двопородні, фінальні гібриди.

DOI: https://doi.org/10.32845/bsnau.lvst.2020.1.9

Подальший прогрес у селекції свиней, який зумовлює зменшення затрат праці, витрат кормів за одночасного підвищення продуктивності значно залежить від використовуваних методів селекції. У племінній роботі з свинарства найбільш поширено три основних методи розведення: внутрішньопородне (чистопородне); міжпородне (схрещування) та гібридизація (породно-лінійна, міжпородна) $[8,14]$.

Відомо, що тривале внутрішньопородне розведення з використанням аутбридингу і лінійного підбору не сприяе подальшому прогресу селекції, особливо за низькоуспадкованими ознаками (відтворні якості маток) та показниками збереженості поросят і їхньої стйкості до захворювань $[23,25,27]$. Тому, поряд із чистопородним розведенням у свинарстві використовують різні форми схрещування. Вони мають дві мети - поліпшення існуючих порід (породотворний процес) та отримання помісного (товарного) молодняку з високими відгодівельними та м'ясними якостями.

Промислове схрещування - це основний метод отримання молодняку свиней для відгодівлі, коли схрещують свиноматок однієї породи з кнурами іншої (двопородне), а трипородне - коли помісних маток

спаровують з плідниками третьої породи. Використовують також варіанти дво- і багатопородного (ротаційного) схрещування, за яких почергово схрещують батьківську або материнську породи.

Тому найбільш прогресивним методом використання наявного генофонду порід і ліній свиней $є$ породно-лінійна гібридизація. Результатом цього методу $\epsilon$ одержання гібридних тварин від плідників і маток спеціалізованих порід, типів та ліній, відселекціонованих на поєднуваність. Цці методи обумовлюють гетерозисний ефрект, що сприяє підвищенню продуктивності свиней на 10-15 \% порівняно 3 чистопородними тваринами $[3,12,17,21]$.

Якщо батьківські форми селекціонують за скороспілістю, оплатою корму, відгодівельними та м'ясними якостями, то для материнської основні ознаки багатоплідність, великоплідність, молочність, маса гнізда на час відлучення, збереженість молодняку [18]. Інші господарськи корисні ознаки підтримуються на середньому рівні, характерному для кожної породи.

Гібридизація - вищий етап схрещування спеціально відселекціонованих материнських і батьківських форм, для яких характерна стійка передача нащадкам відтворювальних, відгодівельних та забійних якостей, що не 
властиво породам, щодо яких проводиться комплексна селекція [24, 26].

У сучасному розумінні, гібридизація - це поєднання (крос) спеціалізованих за окремими ознаками батьківських і материнських порід (ліній) для отримання товарних гібридів. При цьому досягається високий ефект гетерозису i, як результат, відповідно істотне збільшення продуктивності тварин і поліпшення якісних показників продукції $[13,16,19]$.

Сучасне промислове свинарство розвинутих країн світу базується на широкому застосуванні міжлінійного схрещування та гібридизації, які забезпечують стійку й гарантовану передачу потомству високих відтворювальних, відгодівельних та м'ясних якостей, зокрема підвищення багатоплідності (на 5-7\%), середньодобового приросту (на 8-10\%), зниження витрат корму на 1 кг приросту (на 3-5\%) [4, $6,22]$.

Зарубіжні автори [28] повідомляють, що у трипородних гібридів свиноматок у порівнянні 3 чистопородними та двопородними гібридами збільшується маса гнізда (+ 4,2 кг на 21 день), ефекти гетерозису призводять до дещо більшої маси поросят при народженні $(+0,24$ кг порося на гніздо) і до вищої збереженості поросят $(+5,8 \%)$.

Про есрективність трипородної гібридизації у промисловому свинарстві повідомляють й інші дослідження вчених, як ближнього так і далекого зарубіжжя $[5,7,9,10$, $15,20,29]$.

У країнах з розвиненим свинарством великого значення надають виробництву свинини на гібридній основі. Вирішення цієї проблеми здійснюється на базі використання високопродуктивних материнських форм, головним чином порід - велика біла, ландрас та їх помісей, а базовими батьківськими формами є помісні термінальні плідники [2].

Останні десятиріччя більшість промислових господарств 3 виробництва свинини, через недостатній рівень продуктивності свиней вітчизняних порід, завозять тварин зарубіжної селекції. Це завезення не завжди $€$ системним і не завжди науково обгрунтованим. Тому, враховуючи актуальність використання свиней високоспеціалізованих м'ясних генотипів у промисловому свинарстві, було поставлено за мету провести порівняльну оцінку відтворювальних якостей свиноматок ірландської селекції генетичної компанії «Гермітаж» за їх чистопородного розведення, схрещування та гібридизації з кнурами синтетичної лінії «Максгро».

Матеріали та методи дослідження. Експерименти проведено в умовах промислового свинокомплексу ТОВ «НВП «Глобинський свинокомплекс». Досліджувалися чистопородні свиноматки породи ландрас ( великої білої (ОВБ × ठВБ), помісні генотипи - двопородні

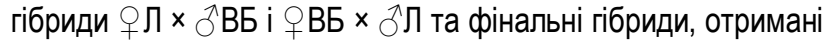
від двопородних свиноматок і кнурів синтетичної лінії

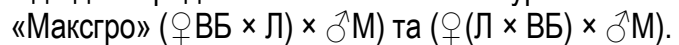

При дослідженні відтворних якостей свиноматок було враховано такі ознаки: кількість народжених та відлучених поросят, маса гнізда поросят при народжені та відлученні, кількість поросят при відлученні та їхня збереженість.

Розвиток молодняку різного походження аналізували за ознаками: маса гнізда поросят при відлученні, приріст живої маси поросят (середньодобовий, абсолютний та відносний), які розраховували за загальноприйнятими у зоотехнії методами [1]. Статистичну обробку даних експериментальних досліджень проводили методами біометрії за формулами, наведеними Е.К. Меркурьевой [11] на ПК з використанням програмного забезпечення Microsoft Excel. Результати вважали статистично достовірними за першого - $\mathrm{P}<0,05$, другого - $\mathrm{P}<0,01$ та третього - $\mathrm{P}<0,001$ порогів достовірності.

Результати досліджень. Порівняльний аналіз показників, які характеризують відтворну здатність чистопородних свиноматок породи ландрас та велика біла, міжпородної різниці не виявив, табл. 1. Оцінка двопородних помісних гібридів, отриманих за реципрокного схрещування,

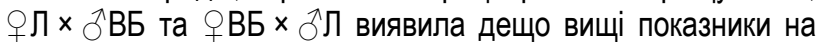
користь свиноматок оВБ $\times$ ЋЛ за кількістю всього народжених поросят (+0,6 гол.), багатоплідністю (+0,56 гол.), масою гнізда при народження (+0,37 кг), масою поросят при відлученні $(+0,23)$ за недостовірної різниці. Проте свиноматки 으 × $\hat{Л}$ поступалися за кількістю поросят при відлученні 3 достовірною різницею на 0,7 гол. $(\mathrm{P}<0,05$; $\mathrm{td}=2,55$ ) за рахунок гіршої збереженості поросят у

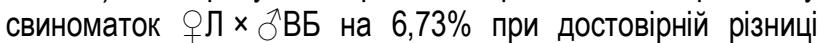
$(P<0,01 ; t d=2,58)$.

За оцінкою показників відтворної здатності фінальних гібридів, отриманих від двопородних свиноматок і кнурів синтетичної лінії «Максгро» (ОВБ $\times$ Л) $\times$ Ј̄ Mr) та $($ ( $(Л \times \mathrm{BБ}) \times \overbrace{}^{\top} \mathrm{Mr})$, кращим за оціненими ознаками виявився молодняк від схрещування на заключному етапі матерів оВБ × Л $з$ кнурами «Максгро». Так, за кількістю всього народжених поросят свиноматки цього поєднання перевищували інші піддослідні групи свиноматок на 0,7-1,76 гол. Достовірна різниця за даною ознакою виявлена при порівнянні 3 I $(P<0,001)$ та III $(P<0,05)$ групами.

За ознакою багатоплідності свиноматки фінального гібриду $\left(\right.$ ВБ × Л) × ${ }^{\top} \mathrm{Mr}$ перевищували решту піддослідних груп з різною мінливістю та ступенем достовірності. Різниця на їхню користь склала від 0,48 (VI група) до 2,3 гол. (I група). Достовірна різниця виявлена у порівнянні 3 III $(P<0,01)$, II та I $(P<0,001)$ групами.

Свиноматки фінального гібриду ( масою поросят при відлученні перевершували усі без виключення підконтрольні групи з високодостовірною різницею $(P<0,001)$ від 0,97, при порівнянні з фінальними гібридами $\bigcirc(Л \times \mathrm{BБ}) \times{ }^{\top} \mathrm{Mr}$, до $1,9 \mathrm{kг}$, при порівнянні 3 групою двопородних гібридів

Від свиноматок фрінального гібриду $($ ВБ $\times$ Л) × $7 \mathrm{Mr}$ отримано найбільшу кількість поросят при відлученні (13,34 гол.), що вище у порівнянні з рештою піддослідних груп від 0,18 (VI група; н/д) до 1,0 гол. (IV група; 0,001).

Єдина ознака, за якою свиноматки фінального гібриду $($ ВБ $\times$ Л) × $\widehat{\nearrow} \mathrm{Mr}$ поступаються усім свиноматкам піддослідних груп - це збереженість поросят. Вони поступалися за цією ознакою з високодостовірною різницею свиноматкам першої $(+11,07 \%$; $P<0,001)$, другої $(+9,33 \%$; $P<0,001)$ та третьої $(+5,97 \% ; P<0,001)$ груп.

Показники вирощування поросят, отриманих від свиноматок піддослідних груп, засвідчили кращі результати

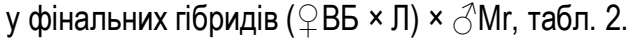


Таблиця 1

Показники відтворної здатності свиноматок ірландської селекції різних генотипів, $x \pm$ S.E.

\begin{tabular}{|c|c|c|c|c|c|c|}
\hline Показник & $\begin{array}{c}\text { ФЛ × }{ }^{\top} Л \\
(\mathrm{n}=70)\end{array}$ & $\begin{array}{c}\text { +QBE } \times \text { BBE } \\
(\mathrm{n}=89)\end{array}$ & $\begin{array}{c}\text { क } \int \times \lesssim B Б \\
(n=50)\end{array}$ & $\begin{array}{c}\text { +BБ } \times \widehat{O} \Omega \\
(n=50)\end{array}$ & 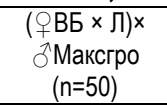 & $\begin{array}{c}f(\text { (Л × ВБ) }) \\
\text { उ'Maксгро } \\
(\mathrm{n}=50)\end{array}$ \\
\hline Група піддослідних тварин & $T$ & II & III & IV & $\mathrm{V}$ & $\overline{\mathrm{VI}}$ \\
\hline Всього народилося поросят, гол. & $16,18 \pm 0,351$ & $17,17 \pm 0,348$ & $16,64 \pm 0,332$ & $17,24 \pm 0,348$ & $17,94 \pm 0,410$ & $17,00 \pm 0,260$ \\
\hline Багатоплідність, гол. & $14,58 \pm 0,287$ & $14,56 \pm 0,281$ & $15,54 \pm 0,296$ & $16,10 \pm 0,363$ & $16,86 \pm 0,346$ & $16,38 \pm 0,202$ \\
\hline Маса гнізда при народженні, кг & $18,98 \pm 0,359$ & $19,03 \pm 0,379$ & $20,53 \pm 0,448$ & $20,90 \pm 0,503$ & $23,27 \pm 0,443$ & $23,35 \pm 0,302$ \\
\hline Великоплідність, кг & $1,30 \pm 0,007$ & $1,31 \pm 0,006$ & $1,32 \pm 0,007$ & $1,30 \pm 0,009$ & $1,38 \pm 0,005$ & $1,39 \pm 0,006$ \\
\hline Маса поросяти при відлученні, кг & $6,75 \pm 0,066$ & $6,78 \pm 0,084$ & $6,22 \pm 0,143$ & $6,45 \pm 0,118$ & $8,12 \pm 0,133$ & $7,15 \pm 0,099$ \\
\hline Кількість поросят при відлученні, гол. & $12,98 \pm 0,084$ & $12,67 \pm 0,144$ & $13,04 \pm 0,185$ & $12,34 \pm 0,203$ & $13,34 \pm 0,275$ & $13,16 \pm 0,175$ \\
\hline Збереженість поросят, \% & $90,19 \pm 1,134$ & $88,45 \pm 1,010$ & $85,09 \pm 1,651$ & $78,36 \pm 2,022$ & $79,12 \pm 0,661$ & $80,61 \pm 0,711$ \\
\hline
\end{tabular}

Примітка:Л - ландрас; ВБ - велика біла.

Таблиця 2

Показники вирощування молодняку свиней, отриманого від свиноматок

ірландської селекції різних генотипів, $\mathrm{X} \pm \mathrm{S}$.E.

\begin{tabular}{|c|c|c|c|c|c|c|}
\hline Показник & 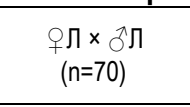 & $\begin{array}{c}\text { OBE } \times \overbrace{}^{2} B \bar{B} 5 \\
(n=89)\end{array}$ & $\begin{array}{c}\text { क } \int \times \bigcirc^{3} B \bar{B} \\
(n=50)\end{array}$ & $\begin{array}{c}+\mathrm{B} E \times \widehat{O}^{\lambda} Л \\
(\mathrm{n}=50)\end{array}$ & $\begin{array}{c}(\text { ВБ } \times \text { Л }) \times \\
\text { ठ Максгро }(\mathrm{n}=50)\end{array}$ & 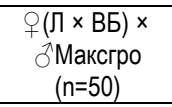 \\
\hline Група піддослідних тварин & $\mathrm{I}$ & II & III & IV & V & $\mathrm{VI}$ \\
\hline $\begin{array}{l}\text { Маса гнізда поросят при } \\
\text { відлученні, кг }\end{array}$ & $87,29 \pm 1,252$ & $86,19 \pm 1,631$ & $81,02 \pm 2,079$ & $79,60 \pm 1,948$ & $108,32 \pm 2,269$ & $93,39 \pm 1,436$ \\
\hline $\begin{array}{l}\text { Приріст живої маси поросят: } \\
\text { середньодобовий, г }\end{array}$ & $201,74 \pm 3,203$ & $202,56 \pm 3,206$ & $181,50 \pm 5,265$ & $190,84 \pm 4,548$ & $249,60 \pm 11,251$ & $213,29 \pm 5,639$ \\
\hline абсолютний, кг & $5,44 \pm 0,086$ & $5,47 \pm 0,087$ & $4,90 \pm 0,142$ & $5,15 \pm 0,123$ & $6,74 \pm 0,304$ & $5,76 \pm 0,152$ \\
\hline відносний, \% & $134,68 \pm 0,862$ & $134,66 \pm 0,808$ & $128,37 \pm 1,983$ & $132,13 \pm 1,276$ & $138,66 \pm 2,096$ & $133,62 \pm 1,332$ \\
\hline
\end{tabular}

Примітка:Л - ландрас; ВБ - велика біла.

Вдале поєднання материнської основи двопородних гібридів з батьківською синтетичною лінією «Максгро» дозволило отримати ефект гетерозису за ознаками приросту живої маси поросят на час їхнього відлучення.

Варто відмітити, що схрещування свиноматок двопородних гібридів ландрас $x$ велика біла з кнурами синтетичної лінії «Максгро» виявилося не таким ефективним у порівнянні з варіантом (Вㄷ $\times$ Л) × ${ }^{\top} \mathrm{Mr}$, але достатньо - у порівнянні з чистопородними свиноматками обох порід (I та II групи) та двопородними гібридами (III та IV групи). Так,

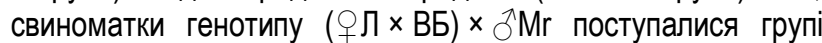

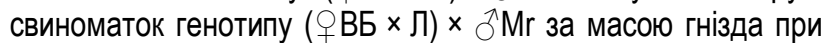
відлученні 3 високодостовірною різницею на 14,93 кг $(\mathrm{P}<0,001)$. Вони також поступалися за показниками приросту живої маси поросят: середньодобовим - на 36,31 г $(\mathrm{P}<0,01)$, абсолютним - на 0,98 кг $(\mathrm{P}<0,01)$ та відносним - на 5,04\% $(P<0,05)$.

Про ефективність використання схрещування у промисловому свинарстві наочно свідчать показники досліджень 3 вирощування поросят, отриманих від свиноматок фінального гібриду $($ В ВБ $\times$ Л $) \times{ }^{7} \mathrm{Mr}$. Порівняльний аналіз потомства цього гібриду з групами поросят, отриманих як від чистопородного розведення порід ландрас та великої білої, так і від їх реципрокного схрещування, засвідчив їхню істотну перевагу за усіма ознаками, які характеризують інтенсивність вирощування молодняку.

Фінальні гібриди $($ (фВБ × Л) × $3 \mathrm{Mr}$ переважають поросят I-IV груп за масою гнізда поросят при відлученні від 21,03 (оЛ × високодостовірної різниці при $\mathrm{P}<0,001$. За приростами живої маси: середньодобовому, абсолютному та відносному

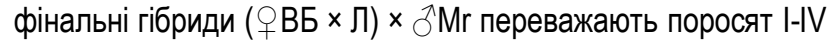
груп з мінливістю відповідно на 47,86-68,10 г ( $\mathrm{P}<0,001), 1,27-$

\section{1,84 кг (P<0,001) та 3,98-10,29 \% (н/д - P<0,001).}

Висновки. Підтверджено, що найбільш ефективним методом задля отримання високих показників відтворних якостей свиноматок у промисловому скотарстві $€$ використання породно-лінійної гібридизації.

Серед фінальних гібридів найбільш вдалим виявилося поєднання двопородних свиноматок (ВБ $\times$ Л) 3 батьківською синтетичною лінією «Максгро», що дозволило отримати ефрект гетерозису за ознаками приросту живої маси поросят на час їхнього відлучення. 


\section{Список використаної літератури:}

1 Басовський М. З., Буркат В. П., Вінничук Д. Т., Коваленко В. П., Ківа М. С., Рубан Ю. Д., Рудик І. А., Сірацький Й. 3. Розведення сільськогосподарських тварин; за ред. М. 3. Басовського. Біла Церква, 2001.152 с.

2. Березовський М. Д. Проблемні питання з удосконалення племінного свинарства в Україні та їх вирішення. Свинарство. 2014. Вип. 64, С. 37-48. 35

3. Бірта Г. О., Бургу Ю. Г. Товарознавство м'яса. Навчальний посібник. К.: Центр учбової літератури, 2011. 164 с.

4. Ващенко П. Відгодівельні якості, ріст та розвиток свиней великої білої породи при поєднанні генотипів вітчизняної та зарубіжної селекції. Тваринництво України. 2004. № 3. С. 18-19.

5. Гарай В., Павлова С., Мальцев Н. Гибридизация - метод реализации гетерозиса. Животноводство России. 2013. № 10. С. 37-38.

6. Герасимов В., Пронь Е. Промышленное скрещивание свиней - основной метод производства товарной свинины. Свиноводство. 2006. № 1. С.5-7.

7. Герасимов В. И. Использование мирового генофронда свиней при разных методах разведения. Свиноводство. 2013. № 6. C. 20-23.

8. Гопка Б. М., Коваленко В. П., Мельник Ю. Ф., Найденко К. А., Нежлукченко Т. І., Пелих В. Г., Рудик І. А., Сахацький М. І., Трофименко О. Л., Угнівенко А. М., Цицюрський Л. М., Шеремета В. І. Селекція сільськогосподарських тварин; за заг. ред. Ю. Ф. Мельника, В. П. Коваленка та А. М. Угнівенка. К.: 2007. 554 с.

9. Гоцай А. "АПК-Инвест": Наши гибриды имеют преимущество перед европейскими. Тваринництво сьогодні. 2011. № 8. C. 48-50.

10. Іванов С. С., Бородаєнко Ф.А. Ефеективне виробництво свинини в умовах СВК «Агрофірма «Миг-Сервіс-Агро». Вісник аграрної науки Причорномор'я. 2015. Вип. 4, Т. 2. С. 78-86.

11. Меркурьева Е. К. Генетические основы селекции в скотоводстве. М.: Колос, 1977. 240 с.

12. Михайлов Н.В., Мамонтов Н. Т. Проблемы селекции и гибридизации свиней. Современные проблемы интенсификации производства свинины: междунар. науч.-практич. конф. 11-13 июля 2007 г.: статьи. 2007. С. 265-274.

13. Никитченко И. Н., Никитенко Р. Н., Горин В. В. Программа гибридизации в свиноводстве Белоруссии на основе селекционно-гибридных центров. Повышение эфффективности свиноводства. М. Агроиздат. 1991. С. 19-28.

14. Онищенко А. О. Промислове схрещування і гібридизація, їх ефеективність у свинарстві. Свинарство, 2013. Вип. 62, C. $72-76$.

15. Пилипенко Н.Ю. Гибридизация - путь к успеху в свиноводстве. Свинарство України. 2012. № 7. С. 4.

16. Плаксин Б., Коряжнов Е., Рыбалко В. Гибридизация свиней в Великобритании. Свиноводство. 1978. № 12. С. 36-38.

17. Стрижак Т. А., Мартинюк І. М., Мірошникова О. С. Відтворювальні якості кнурів породи ландрас вітчизняної та зарубіжної селекції. Міжвідом. темат. наук. зб. «Свинарство». 2014. Вип. 64. С. 57-60.

18. Суслина Е. Н., Новиков А. А. Методические аспекты повышения эффрективности гибридизации в свиноводстве. Свиноводство. 2011. №4. С.12-15.

19. Шейко И. П. Особенности селекционного процесса при специализации различных типов и пород свиней и их сочетаемость в локальных системах гибридизации: авторефр. дис. ... канд. с.-х. наук: спец. 06.02.01. Разведение и селекция животных. М.: 1986.43 с.

20. Шейко И. П., Смирнов В. С. Свиноводство. М.: Новое издание, 2005. 384 С.

21. Andronie I., Adnronie V., Parvu M. [et al.] Behavi our and productive performance of pregnant sows according to the housing system. Bul. Univ. Agr. Sci. and Vet. Med., Cluj-Napoca. Vet. Med. 2010. Vol. 67. N 1., pp. 12-16.

22. Cassady J. P., Young L. D., Leymaster K. A. Heterosis and recombination effects on pig growth and carcass traits. J. Anim Sci. 2002 Sep; 80(9):2286-302.

23. Holm B. et al. Genetic correlations between reproduction and production traits in swine. J. Anim. Sci. 2004. 2:34583464.

24. Hopler E. Das österreichische Hybrid. Schwe in. Prakt. Land, techu. 1980. Bd. 33. № 1. S. 10-12.

25. Krupa E., Wolf J. Simultaneous estimation of genetic parameters for production and litter size traits in Czech Large White and Czech Landrace pigs. Czech J. Anim. Sci. 2013. 58(9):429-436.

26. Oseni S. Evaluation of the F1 and backcrosses of Nigerian local pig sand the Large White for litter characteristics in Southwest Nigeria. Livestock Research for Rural Development. 2005. 17(4) pp. 12-16.

27. Shull G. H. Hybridization methods in corn breeding. Amer. Breeding Magazine. 1981. 1., P. 98-107.

28. Van V. T. K., Due N. V. Heritabilities, genetic and phenotypic correlations between reproductive performance in Mong Ca1 and Large White breeds. Proc. Assoc. Advmt/Anim. Breed. Genet. 1999.Vol.13.

29. Nwakpu P. E., Ugwu S. O. C. Heterosis for litter traits in native by exotic inbred pig crosses. Journal of Tropical Agriculture, Food, Environment and Extension. 2009. Vol. 8. N. 1 pp. 31-37.

\section{References:}

1. Basovskyi, M. Z., Burkat, V. P., Vinnychuk, D. T., Kovalenko, V. P., Kiva, M. S., Ruban, Yu. D., Rudyk, I. A. and Siratskyi, Y. Z., 2001. Rozvedennia silskohospodarskykh tvaryn [Breeding of farm animals]. Bila Tserkva.

2. Berezovskyi, M. D., 2014. Problemni pytannia z udoskonalennia pleminnoho svynarstva v Ukraini ta yikh vyrishennia [Problematic issues of improving pedigree pig breeding in Ukraine and their solution]. Svynarstvo, issue. 64, pp. 37-48.

3. Birta, H. O. and Burhu, Yu. H., 2011. Tovaroznavstvo miasa: navchalnyi posibnyk [Meat commodity science: tutorial]. 
Kyiv: Tsentr uchbovoi literatury. 164.

4. Vashchenko, P., 2004. Vidhodivelni yakosti, rist ta rozvytok svynei velykoi biloi porody pry poiednanni henotypiv vitchyznianoi ta zarubizhnoi selektsii [Fattening qualities, growth and development of Large White pigs with a combination of genotypes of domestic and foreign selection]. Tvarynnytstvo Ukrainy, no. 3, pp. 18-19.

5. Garay, V., Pavlova, S. and Mal'tsev, N. 2013. Gibridizatsiya - metod realizatsii geterozisa [Hybridization - the method of implementation of heterosis]. Zhivotnovodstvo Rossii, no. 10, pp. 37-38.

6. Gerasimov, V. and Pron', E., 2006. Promyshlennoe skreshchivanie sviney - osnovnoy metod proizvodstva tovarnoy svininy [Industrial crossbreeding of pigs - the main method of commercial pork production]. Svinovodstvo, no. 1, pp. 5-7.

7. Gerasimov, V. I., 2013. Ispol'zovanie mirovogo genofonda sviney pri raznykh metodakh razvedeniya [Using global gene pool of pigs at different methods of breeding]. Svinovodstvo, no. 6, pp. 20-23.

8. Melnyk, Yu. F., Kovalenko, V. P. and Uhnivenko, A. M. eds., 2007. Hopka, B. M., Kovalenko, V. P., Melnyk, Yu. F., Naidenko, K. A., Nezhlukchenko, T. I., Pelykh, V. H., Rudyk, I. A., Sakhatskyi, M. I., Trofymenko, O. L., Unnivenko, A. M., Tsytsiurskyi, L. M. and Sheremeta, V. I. Selektsiia silskohospodarskykh tvaryn [Breeding of farm animals]. Kyiv.

9. Gotsay, A., 2011. "APK-Invest": Nashi gibridy imeyut preimushchestvo pered evropeyskimi [APK-Invest: Our hybrids have an advantage over European ones]. Tvarynnytstvo sohodni, no. 8, pp. 48-50.

10. Ivanov, S. S. and Borodaienko, F.A. 2015. Efektyvne vyrobnytstvo svynyny v umovakh SVK "Ahrofirma "Myh-ServisAhro" [Efficient production of pork in terms of APC "Agricultural company" Mig-Service-Agro"]. Visnyk ahrarnoi nauky Prychornomoria, issue. 4, vol. 2, pp. 78-86.

11. Merkur'eva, E. K., 1977. Geneticheskie osnovy selektsii v skotovodstve [Genetic principles of selection in livestock]. Moskva: Kolos.

12. Mikhaylov, N. V. and Mamontov, N. T., 2007. Problemy selektsii i gibridizatsii sviney [Problems of selection and hybridization of pigs]. Sovremennye problemy intensifikatsii proizvodstva svininy, Proceedings of the International Conference, July 11-13, 2007. pp 265-274.

13. Nikitchenko I.N., Nikitenko R.N. and Gorin V.V., 1991. Programma gibridizatsii v svinovodstve Belorussii na osnove selektsionno-gibridnykh tsentrov. Povyshenie effektivnosti svinovodstva [Hybridization program in pig breeding in Belarus on the basis of selection and hybrid centers. Improving the efficiency of pig breeding]. M.: Agroizdat.

14. Onyshchenko, A. O., 2013. Promyslove skhreshchuvannia i hibrydyzatsiia, yikh efektyvnist u svynarstvi [Industrial crossbreeding and hybridization, their effectiveness in pig breeding]. Svynarstvo, issue. 62, pp. $72-76$.

15. Pilipenko, N. Yu., 2012. Gibridizatsiya - put' k uspekhu v svinovodstve [Hybridization - the path to success in pigbreeding]. Svinarstvo Ukraïni, no. 7, pp. 4.

16. Plaksin, B., Koryazhnov, E. and Rybalko, V., 1978. Gibridizatsiya sviney v Velikobritanii [Pig hybridization in the UK]. Svinovodstvo, no. 12, pp. 36-38.

17. Stryzhak, T. A., Martyniuk, I. M. and Miroshnykova, O. S., 2014. Vidtvoriuvalni yakosti knuriv porody landras vitchyznianoi ta zarubizhnoi selektsii [Reproductive qualities of Landrace boars of domestic and foreign selection]. Mizhvidom. temat. nauk. zb. «Svynarstvo», issue. 64, pp. 57-60.

18. Suslina, E. N. and Novikov, A. A., 2011. Metodicheskie aspekty povysheniya effektivnosti gibridizatsii v svinovodstve [Methodological aspects of increasing the efficiency of hybridization in pig breeding]. Svinovodstvo, no. 4, pp. 12-15.

19. Sheyko, I. P., 1986. Features of the breeding process in the specialization of various types and breeds of pigs and their compatibility in local hybridization systems. Abstract of Ph.D. dissertation. Moscov.

20. Sheyko, I. P. and Smirnov, V. S., 2005. Svinovodstvo [Pig breeding]. M.: Novoe izdanie.

21. Andronie I., Adnronie V., Parvu M. [et al.], 2010. Behaviour and productive performance of pregnant sows according to the housing system. Bul. Univ. Agr. Sci. And Vet. Med., Cluj-Napoca. Vet. Med., vol. 67, no. 1, pp. $12-16$.

22. Cassady, J. P., Young, L. D. and Leymaster, K. A., 2002. Heterosis and recombination effects on pig growth and carcass traits. Anim. Sci. Sep; vol. 80(9), pp. 2286-302.

23. Holm, B. et al., 2004. Genetic correlations between reproduction and production traits in swine. J. Anim. Sci., vol. 2, pp. 3458-3464.

24. Hopler, E., 1980. Das österreichische Hybrid. Schwein. Prakt. Land, techu. Bd., vol. 33, 1, pp. 10-12.

25. Krupa, E. and Wolf, J., 2013. Simultaneous estimation of genetic parameters for production and litter size traits in Czech Large White and Czech Landrace pigs. Czech J. Anim. Sci., vol. 58(9), pp. 429-436.

26. Nwakpu, P. E. and Ugwu, S. O. C., 2009, Heterosis for litter traits in native by exotic inbred pig crosses. Journal of Tropical Agriculture, Food, Environment and Extension, vol. 8, no. 1, pp. 31-37.

27. Oseni, S., 2005. Evaluation of the F1 and backcrosses of Nigerian local pigs and the Large White for litter characteristics in South west Nigeria. Livestock Research for Rural Development, vol. 17(4), pp. 12-16.

28. Shull, G. H., 1981. Hybridization methods in corn breeding. Amer. Breeding Magazine. vol. 1., pp. 98-107.

29. Van, V. T. K. and Due, N. V., 1999. Heritabilities, genetic and phenotypic correlations between reproductive performance in Mong Ca1 and Large White breeds. Proc. Assoc. Advmt/Anim. Breed. Genet. vol. 13.

Karpenko Bogdan Mykolayovych, graduate student, Sumy National Agrarian University

Economically useful qualities of sows landrace and large white for purebred breeding, crossbreeding and hybridization in conditions of industrial crossing

The reproductive qualities of sows of different origins of Irish selection: purebred Landrace ( $\left.\$ L \times \hat{}{ }^{\lambda} L\right)$, Large White

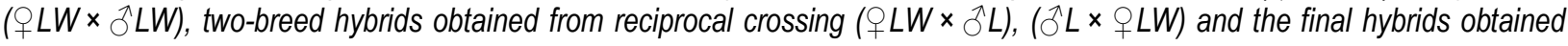


from crosses of two-breed hybrid sows with boars of the synthetic line "Maxgro" (Mr) were investigated.. The experiments were carried out in the conditions of an industrial pig-breeding complex of LLC "SPE" Globinskyi pig farm. Comparative analysis of the indicators characterizing the reproductive ability of purebred sows of Landrace and Large White breeds did not reveal any interbreed difference. Evaluation of two-breed hybrids, $+{ }^{2} \times \times{ }^{\lambda} L W$ and $O L W \times{ }^{\lambda} L$ found slightly higher indices in favor of O $L W \times \widehat{ } \mathrm{L}$ sows in terms of the number of piglets born ( 0.6 heads), multiple pregnancies $(+0.56$ heads), weight nests at birth $(+0.37 \mathrm{~kg})$, weight of piglets at weaning $(+0.23)$ with an unreliable difference. However, $ᄋ \quad L W \times{ }^{\lambda} L$ sows were inferior by the number of piglets at weaning with a significant difference of 0.7 heads. $(P<0.05)$ due to the poorer preservation of piglets in

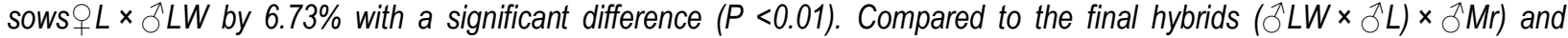
$\left(\right.$ P $\left.(L \times L W) \times{ }^{\lambda} M r\right)$, the young animals from the crossing of mothers ${ }^{\lambda} L W \times{ }^{\lambda} L$ with "Maxgro" boars turned out to be the best according to the estimated traits. So, in terms of the total number of piglets born, sows of this combination exceeded other experimental groups of sows by 0.7-1.76 heads. A significant difference by this trait was found when comparing with I $(P<0.001)$ and III $(P<0.05)$ groups. The successful combination of the matemal base of two-breed hybrids with the parental synthetic line "Maxgro" made it possible to obtain the effect of heterosis on the basis of live weight increase in piglets during their weaning. The best combination of the final hybrid $(\& L W \times L) \times{ }^{\top} \mathrm{Mr}$, which exceeded the final hybrids $(\mathrm{Q} L \times L W) \times{ }^{\top} \mathrm{Mr}$ by nest weight at weaning by $14.93 \mathrm{~kg}(P<0.001)$, by indicators of live weight gain of piglets : average daily - by $36.31 \mathrm{~g}(P<0.01)$, absolute - by $0.98 \mathrm{~kg}(P<0.01)$ and relative - by $5.04 \%(P<0.05)$. They also predominated piglets obtained from purebred sows and their two-

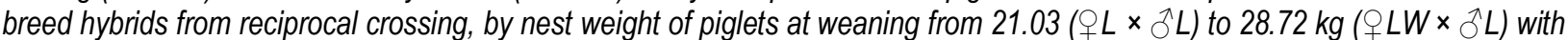
a highly reliable difference at $P<0.001$. In terms of live weight gain: average daily, absolute and relative, final hybrids $(O C W \times L) \times{ }^{7} M r$, dominated by piglets in I-IV groups with variability $47.86-68.10 \mathrm{~g}$, on $(P<0.001), 1.27-1,84 \mathrm{~kg}(P<0.001)$ and 3.98-10.29\% (n / $-P<0.001)$, respectively.

Key words: Landrace, Large White, maksgro, breed, sows, piglets, reproductive qualities, two-breed, final hybrids.

Дата надходження до редакції: 01.02.2020 p. 